\title{
Critical incidents connected to nurses' leadership in Intensive Care Units
}

\author{
Incidentes críticos relacionados à liderança do enfermeiro em Centros de Terapia Intensiva \\ Incidentes críticos relativos al liderazgo del enfermero en Centros de Terapia Intensiva
}

\section{Elaine Cantarella Lima', Andrea Bernardes', Priscila Lapaz Baldo', Vanessa Gomes Maziero', Silvia Helena Henriques Camelo', Alexandre Pazetto Balsanelli"}

\author{
' Universidade de São Paulo, Ribeirão Preto College of Nursing, Postgraduate Program Basic Nursing. \\ Ribeirão Preto, São Paulo, Brazil. \\ "Universidade Federal de São Paulo, São Paulo School of Nursing, \\ Department of Administration in Health Care and Nursing Services. São Paulo, Brazil.
}

How to cite this article:

Lima EC, Bernardes A, Baldo PL, Maziero VG, Camelo SHH, Balsanelli AP. Critical incidents connected to nurses' leadership in intensive care units. Rev Bras Enferm [Internet]. 2017;70(5):1018-25. [Thematic Edition "Good practices and fundamentals of Nursing work in the construction of a democratic society"] DOI: http://dx.doi.org/10.1590/0034-7167-2016-0137

Submission: 04-28-2016

Approval: 03-10-2017

\section{ABSTRACT}

Objective: The goal of this study is to analyze nurses' leadership in intensive care units at hospitals in the state of São Paulo, Brazil, in the face of positive and negative critical incidents. Method: Exploratory, descriptive study, conducted with 24 nurses by using the Critical Incident Technique as a methodological benchmark. Results: Results were grouped into 61 critical incidents distributed into categories. Researchers came to the conclusion that leadership-related situations interfere with IC nurses' behaviors. Among these situations they found: difficulty in the communication process; conflicts in the daily exercise of nurses' activities; people management; and the setting of high quality care targets. Final considerations: Researchers identified a mixed leadership model, leading them to the conclusion that nurses' knowledge and practice of contemporary leadership theories/styles are crucial because they facilitate the communication process, focusing on behavioral aspects and beliefs, in addition to valuing flexibility. This positively impacts the organization's results. Descriptors: Leadership; Nursing; Critical care; Nurse; Intensive care.

\section{RESUMO}

Objetivo: Analisar a liderança do enfermeiro em Centros de Terapia Intensiva de hospitais localizados no interior do estado de São Paulo, diante de incidentes críticos positivos e negativos. Método: Estudo exploratório, descritivo, realizado com 24 enfermeiros, que utilizou a Técnica do Incidente Crítico como referencial metodológico. Resultados: Os resultados foram agrupados em 61 incidentes críticos distribuídos em categorias. Identificou-se que situações relacionadas à liderança interferem no comportamento do enfermeiro de Terapia Intensiva, dentre elas: dificuldade no processo de comunicação, conflitos existentes no dia a dia do exercício profissional, gerenciamento de pessoas e estabelecimento de metas para o alcance da assistência qualificada. Considerações finais: Encontrou-se um modelo misto de liderança, o que permite concluir que o conhecimento e a prática dos enfermeiros acerca de teorias/estilos contemporâneos de liderança tornam-se fundamentais, pois facilitam o processo de comunicação, focando nos aspectos comportamentais e crenças, e valorizam a flexibilidade, impactando positivamente os resultados da organização.

Descritores: Liderança; Enfermagem; Cuidados Críticos; Enfermeiro; Terapia Intensiva.

\section{RESUMEN}

Objetivo: Analizar el liderazgo del enfermero en Centros de Terapia Intensiva de hospitales del interior del estado de São Paulo, ante incidentes críticos positivos y negativos. Método: Estudio exploratorio, descriptivo, realizado con 24 enfermeros, utilizando la Técnica del Incidente Crítico como referencial metodológico. Resultados: Los resultados fueron agrupados en 61 incidentes críticos, distribuidos en categorías. Se identificó que situaciones relativas al liderazgo interfieren en la conducta del enfermero de Terapia Intensiva, entre ellas: dificultades del proceso de comunicación, conflictos diarios del ejercicio profesional, gestión de personas y establecimiento de metas para alcanzar la atención calificada. Consideraciones finales: Se encontró un modelo mixto de liderazgo, que permite concluir en que conocimiento y práctica de los enfermeros acerca de teorías/estilos 
contemporáneos de liderazgo resultan fundamentales, pues facilitan el proceso de comunicación, enfocándose en los aspectos conductuales y en creencias, y valoran la flexibilidad, impactando positivamente en los resultados de la organización.

Descriptores: Liderazgo; Enfermería; Cuidados Críticos; Enfermero; Terapia Intensiva.

\section{CORRESPONDING AUTHORＡndrea BernardesＥ-mail: andreab@eerp.usp.br}

\section{INTRODUCTION}

Intensive care units are an environment that provides high complexity and long-term care, involving a sequence of invasive and complex procedures, where situations that demand quick and safe decision making are common ${ }^{(1)}$. The care for high complexity patients is part of Brazil's current health care policy context, and modern hospital institutions have been attracting attention because they care for patients in increasingly critical health states ${ }^{(2)}$.

In this scenario, the nursing team must have abilities that guarantee technical and scientific rigor in the care given to patients, whereby nurses are responsible for developing care and management activities, in addition to being responsible for higher complexity caregiving ${ }^{(3)}$. Because of the intense activities performed during shifts in intensive care units, which happen in a busy, stressful environment, thorough attention and care are demanded from all workers. This will eventually overload the entire team and directly and negatively impact patients' recovery ${ }^{(4)}$.

In this sense, the role of leaders as motivators and mediators of relations in this environment becomes essentially important. Thus, more contemporary leadership theories are appropriate, especially in those realities where the management model is more decentralized and empowering, valuing and intensifying interpersonal relations.

Leadership consists of the influence by a leader who stands out from his or her group because of his or her ideas in search of common goals. In a healthcare team, leadership can be exerted by any of its members, including nurses, who are qualified professionals and a reference to their team.

With the complexity of current times, there is a need for a broader view of knowledge. Therefore, training professionals with leadership knowledge, skills, and abilities is paramount ${ }^{(5)}$.

Leadership and management are abilities that may be developed by different people inasmuch as organizations depend not only on leaders but also on managers. Whereas the first focus on the outer world, the latter must stick with the company's internal world in order to make the leader's revolutionary ideas attainable ${ }^{(6)}$, as the leader is the one who influences the group to reach good results. Managers, in turn, have a formal position and exert administrative control within the group.

In intensive care units, the coordination and management of care must be based on decision-making skills; thus, leadership is considered to be one of the main abilities to be developed, favoring a safe environment for providing high quality care. In addition to taking care of users' health needs by providing high complexity care, nurses in these units are seen as articulators of a multiprofessional team; therefore, they are the professionals who must lead ${ }^{(7-8)}$.

In this context, it is possible to observe the importance of having innovative leaders in this environment, especially when participative management is adopted to decentralize power and authority, create shared problem-solving strategies, and use simpler and more straightforward information systems ${ }^{(9)}$.

Despite the abovementioned, studies that identify leadership styles and/or experiences experienced by nurses in intensive care units are incipient. Therefore, there is a need for more scientific evidence to support professional practice in this high complexity scenario.

There is little research involving leadership styles. Studies on leadership in nursing have addressed the following aspects: the association between leadership and workload; perceptions of nursing specialists and assistants of the role of leader played by nurses; and leadership as a skill(10).

In view of this problem, the following questions can be asked: What is nurses' leadership in intensive care units like? Which positive and negative situations influence the leadership by nurses in intensive care units? What are the easy and difficult aspects of the exercise of this leadership?

Nurses' leadership in ICUs must intervene in the team's work process so that identifying the facilitating and limiting aspects of this leadership can help improve the quality of care given to patients. As this stimulates an efficient communication process and teamwork, it will enhance co-responsibility in terms of the results and engagement to meet goals ${ }^{(11)}$.

Therefore, the goal of this study is to analyze nurses' leadership in intensive care units at hospitals in the state of São Paulo, Brazil, in the face of positive and negative critical incidents.

\section{METHOD}

\section{Ethical aspects}

This project was approved by the Ribeirão Preto School of Nursing's Ethics Committee, and participants signed a Free Consent Term according to Resolution 466/12.

\section{Theoretical and methodological frameworks}

The critical incident technique was adopted as a theoretical and methodological benchmark for this study. It is defined as the set of procedures for the collection of direct observation of human behavior to facilitate its potential use in solving practical problems and develop broad psychological principles ${ }^{(12)}$.

It is necessary to clarify that critical incidents are recognized as relevant situations observed or reported by interviewees. In nursing, the critical incident technique has been used because it is a practical method that enables researchers to understand the complexity of nurses' role and position, based on these professionals' behaviors during their professional exercise ${ }^{(13)}$.

\section{Study type}

This study is descriptive and exploratory, conducted by using the technique of critical incident, whose reported 
situations enabled researchers to identify positive and negative aspects in the leadership developed in intensive care units, in addition to easy and difficult events experienced by nurses as a result of this leadership development.

\section{Study setting}

This study was conducted at a public hospital, a charity hospital, and a private for-profit hospital in a city in the state of São Paulo, Brazil.

The public institution is regarded as an autonomous body with a corporate registration and its own assets, working with administrative and financial autonomy. The institution works as a round-the-clock emergency hospital and it is referenced as a tertiary hospital, particularly for patients in urgency or medical emergency situations. In addition to the urgency room, the hospital provides hospitalization in the areas of gynecology, orthopedics, pediatrics, as well as intensive care beds (adult and child intensive care units), a burn patient unit, and a semi-intensive care unit. There are isolation units and outpatient clinics in the areas of clinical surgery, general practice, child neurology, neurosurgery, gynecology, pediatrics, infectious diseases, head and neck surgery, orthopedics, and psychiatry ${ }^{(14)}$.

The for-profit private hospital is a reference for high-complexity procedures, focusing on neurology, cardiology, orthopedics, and bariatric surgery. Additionally, the following services are offered: a blood bank; surgical theater; intensive care unit; materials sterilization unit; hemodynamics; clinical analyses laboratory; nuclear medicine; 24-hour emergency room; radiology; inpatient; and urology units. Care is given on a private and health insurance basis ${ }^{(15)}$.

The charity hospital was conceived with the goal of providing health care to all who call. It is located in the central area of the city and receives, on average, $80 \%$ of its patients from the Brazilian Comprehensive Health service. The institution provides the following specialized and diagnostic services: general hospital; 24-hour emergency room for urgency/emergency cases; inpatient and outpatient clinics; histopathology; cytopathology; digestive endoscopy; physical therapy; hemodynamics; hemotherapy; clinical pathology; and radiotherapy. It offers public, private, and insurance-based health care ${ }^{(15)}$.

It is worth highlighting that the management models adopted at the institutions where data were collected are highly hierarchical, with well-defined authority lines.

The study inclusion criteria consisted of the nurses' presence at the hospital during the data collection period and admission to work as of 2011 or before. Researchers chose to use this last criterion because they deemed it important for nurses to have experienced the management model adopted by each of the institutions, as well as the leadership type used in intensive care units.

\section{Study sample}

Of the 32 nurses who were present at the researched institutions, 26 were included in the study, as the others did not meet the inclusion criteria. Of these, two refused to participate; thus the final total was 24 nurses. Twenty of the professionals were assistant nurses and four held a management position and worked in intensive care units.

\section{Data collection and organization}

Researchers chose to interview all of the professionals who were available and agreed to participate in this study. Data collection took place in the months of November and December 2014, and was performed by the main researcher, by means of an interview with the nursing team, in a private environment, to identify aspects related to nurses' leadership. The semi-structured interview requested detailed accounts of situations experienced or witnessed by each one of the interviewees concerning nurses' leadership in the intensive care unit. Participants were asked to talk about a situation they experienced, either positive or negative, whose aspects could refer to leadership. Interviewees talked about what had happened, what the people involved did, how they did it, and what resulted from this situation, and elaborated on the easy and difficult aspects of performing their role. After interviewees gave their permission, the interviews were recorded and transcribed by the researcher.

\section{Data analysis}

To collect the critical incidents from the 24 interviews, it was necessary to submit the participants' accounts to content analysis, which enabled the identification of three categories in terms of their theme ${ }^{(16)}$, namely: interventions at the work environment; establishing targets for the quality of care; and nurses' performance in people management.

It is important to underline that fictitious names were given to participants and codes were adopted (E1, E2,... E9) to guarantee their anonymity.

\section{RESULTS}

Of the interviewed sample, 20 professionals were female (83\%), with an age range between 25 and 35 years (58\%). Regarding their professional time, most of them had been working as nurses for three to eight years (46\%). Seven professionals had been working as nurses for nine to 14 years (29\%) and six (25\%) had been working as nurses for more than 14 years. Of the interviewed professionals, $11(46 \%)$ had additional studies in management and intensive care and the majority (54\%) worked at the public institution.

Participants mentioned both positive and negative aspects of nurses' leadership in intensive care units.

The 24 interviews resulted in 61 critical incidents, that is, specific situations that allowed for the analysis of the experienced or witnessed fact. The accounts that did not include experienced or witnessed situations were disregarded because they did not characterize critical incidents; rather, they expressed professionals' opinions.

Analysis of the accounts enabled researchers to group critical incidents into categories: interventions in the work environment; establishing targets for the quality of care; and nurses' performance in people management. The stories presented the situations, behaviors, and consequences related to nurses' leadership in intensive care units. 


\section{Interventions in the work environment}

This category is concerned with situations related to professionals' interventions in the workplace, highlighting both positive and negative perceptions of nurses' leadership.

It is important to underline that the stories were told by nurses who give direct care to patients and did not hold management positions at their respective institutions.

One can notice that nurses mentioned goals reached through procedures conducted during the exercise of leadership and the following stories show this.

... Now we have a very heavy patient, a quadriplegic, obese patient. I asked about taking this patient to shower and putting him in the armchair. And when I said: "Guys, let's lift up this patient," the entire unit-we were nine here, including the doctor-everybody came up, lifted the patient up, took him off his bed, put him in the bath chair, took him to the shower, took the patient back to the armchair, left him there sitting for a while and then everybody got together to take him back to his bed, you know? In this situation I felt like I was the leader. (E11)

... One day I was on my shift and a patient was undergoing dialysis. I realized the patient was crashing, so I chose to disconnect the dialysis machine, asked the nursing specialist to call the doctor, asked another person to bring the kart and went up to massage him... I said: "You, get the phone to call the doctor; you, fetch the urgency kart..." Then I took turns to massage because I'm not able to massage all the time. I left the massage and went outside to help suction the medications while the boys took turns between ambu bag and massage. I delegate jobs and work together with my team. I think it's very common for us in our daily lives here to have this kind of leadership. The result was positive. Everybody cooperated. (E3)

It is also possible to observe that goals are not always reached, which was characterized as an example of a negative situation, as seen in the story below.

... A dressing was supposed to be tried on the pressure ulcer. I didn't know how to use this dressing, so I asked the nursing specialist to put on the dressing the way I thought it should be placed. The entire dressing. I told the person in charge about it the next day and she said we were supposed to put on just a piece of it. And she asked me: "Didn't they tell you?" And I said: "No, they didn't." So the result was that we wasted some material, you know? What I could have used in two dressings, for example, I put on the plate and used for only one. I guess this is negative leadership because we must share information more often. And this has to come from our leaders. (E4)

\section{Establishing targets for the quality of care}

The category "Establishing targets for quality of care," which had exclusively positive references, dealt with nursing actions related to the achievement of objectives regarding nursing care to reach established goals:

... I needed to cut the overtime rate by $70 \%$ at the ICU so I spoke to the whole specialists' team and nurses. I suggested that we had to cut the overtime rate by $70 \%$ and I had some plans for changes in schedule, but I wanted them to help me decide on that. As a consensus, together with the team, we defined together who was going to change their own schedule. I explained that if we cut the overtime rate, we could help bring pneumatic mattresses to 19 beds of the ICU and replace the two respirators that we wanted to replace, in addition to two defibrillators that we wanted to replace by newer equipment. We changed our schedules, cut overtime by $63 \%$, and have already replaced the defibrillators and respirators, and have been able to get 14 pneumatic mattresses for the ICU. (E14)

... We had many cases of skin injuries, pressure ulcers, and it was difficult to involve the group, so I introduced a quality indicator, you know, to work with this indicator and to try and reduce the pressure ulcer rate. I learned about a certification program. So I enrolled the group in this program. They come over, train the group, and recognize the workers for best practices. I scheduled a lesson on preventing pressure ulcers with the entire team. Not only with nurses, but the entire team: the specialists and assistants. Then we had just positive facts. Our rate dropped and improved a lot. I was able to mobilize the team to work together and the result was impressive. (E22)

The previous stories were told by nurses who have a management position at their respective institutions. It is possible to observe that fulfilling goals to reach the targets is connected with the direct care to patients, as well as managing people. The importance of engaging the work team for the achievement of goals and reaching the target to improve the care given to patients through the exercise of efficient leadership is evident.

\section{Nurses' performance in people management}

The last category of the critical incidents emphasizes that people management is one of the nurses' main management assignments. When it is well performed, it enables a quality increase in the care given:

... There was another situation. I wrote the carnival schedule this year. And what did I do? I saw the previous schedule and found the nurses who had not taken carnival off the previous year. So I gave them the day off. And there's a nurse who always takes carnival off; I scheduled him to work and he didn't show up. And of course the people who took carnival off were happy. One of them had worked the two previous years; another one had worked the three previous years and didn't take it off because she didn't need it, but this year she did. This was a positive leadership situation. (E17)

... Two shifts ago, a nurse who was responsible for the coronary unit shift needed support from our ICU nursing specialists. The workers looked at our schedule and someone had to leave to help the coronary unit. And they didn't want to leave this sector. So I had a meeting with them. I asked them: "Why won't you leave? Which criteria do you use for not leaving here and helping another sector?" So one of them answered: "I'm the oldest in the house." And I 
said: "Well, the question of being the oldest doesn't matter. Here at this institution you can't just come and work for one sector only. Everybody needs to work at all the routines. So we're going to set up a rotation schedule for the days someone needs to leave the ICU to fill in for another sector. Today it was you; next time someone else will go, and a different person on the next to be fair to everybody." So they said: "OK, let's keep this schedule." Now we've been using this rotation schedule both in the coronary unit and here at the ICU. This was a positive situation. (E6)

It is possible to infer from the previous accounts that the use of a rotation schedule, in addition to the number of staff, has an important impact in managing people. In the story by Nurse 17 , the creation of a carnival schedule created satisfaction among the team members who took the day off on this holiday; however, it also resulted in the absence of a worker who was not happy with the schedule.

The story by Nurse 6 , in turn, is related to the resolution of conflict caused by the daily working schedule. By being on duty, the nurse would have to choose an employee to leave the ICU and help the coronary unit. When he faced the professionals' refusal to leave the ICU, the nurse dialogued with the team and proposed the creation of a rotation schedule to be fair to all, and that was accepted by the workers.

Nurses tried to create a fair rotation schedule to solve problems related to staff size, which may lead to conflicts in the team. Paradoxically, creating a monthly or daily schedule as a way to exercise coercive power leads to questionings by the team and may result in unplanned absences that harm the work organization.

\section{DISCUSSION}

Researchers were able to observe in the sample studied that nurses relate to the exercise of leadership and interventions that take place daily in the situations they experience.

An intensive care unit is characterized by the permanence of critically ill patients who need a professional team with specific abilities, and leadership is among them. This leadership performed by nurses must favor the articulation between the care and management dimensions ${ }^{(17)}$.

It is possible to observe this articulation in the performance of interventions as nurses delegate jobs, organize their work, and act together with their team members. When goals are reached, nurses relate the positive results of that particular situation to the exercise of leadership. Nonetheless, it is well known that the use of this tool must not be perceived from the performance of interventions only. Leadership encompasses a broader context where nurses must take part to play the role of team leaders.

Studies prove that leadership by nurses that is task-centered reduces team satisfaction, whereas the leadership styles that focus on personal relations enhance productivity and results in the work environment ${ }^{(18)}$.

In this sense, more contemporary leadership theories are more adequate, as is the case with Transformational Leadership theory, Authentic Leadership theory, and Situational
Leadership theory. What they have in common is the focus on studying leaders who have managed to achieve excellent results at their work ${ }^{(19-20)}$.

Transformational leaders lead their team to a high level of motivation through a relationship based on confidence, value creativity and innovation, and are attentive to their team members' concerns and needs ${ }^{(21)}$. Authentic leaders involve their team in their decisions, resulting in an increase in confidence and greater engagement and satisfaction at work ${ }^{(22)}$.

Situational leadership theory, in turn, states that there is no single leadership style to be used in every situation. Choosing the leadership style to be adopted will depend on the work team; thus, the behavior of the group members will point to the appropriate actions. The interaction between leaders and their team is extremely important, as well as the way interpersonal relations are established for the achievement of goals $s^{(5)}$. When these goals are not reached, nurses relate the exercise of leadership to a negative situation.

In the exercise of negative leadership, there are failures in the communication process, in addition to lack of knowledge and attention when performing an intervention, and this prevents the achievement of the goals set.

In an organization, the main intent of communication is to favor knowledge and changes in behaviors and attitudes. Interpersonal relationship is an important element for the success of the communication resulting from the meeting of at least two individuals. However, the type of organization at work and the lack of engagement in the team are hindering factors for the communication process ${ }^{(23)}$. Additionally to being fundamental for effective management and decision making, communication skills are key for efficient leadership and help the organization reach its goals ${ }^{(24)}$.

To achieve goals in face of healthcare needs, institutions increasingly demand that leadership abilities be performed by nurses who care directly for patients ${ }^{(17)}$.

Another situation related to nurses' leadership in intensive care units has to do with the setting of targets for high quality care. The importance of engaging the work team for the achievement of goals and reaching the target to improve the care given to patients through the exercise of efficient leadership is evident.

When involving the team in the decision-making process, the nurse was able to solve problems and showed maturity and security. Counting on the support and co-responsibility of the workers' group, he achieved the expected results, positively impacting both patients-who benefited from the use of replacement permanent materials and equipment-and workers and the institution themselves, showing the importance of using flexible and innovative leadership.

In this sense, to practice the ability to lead nurses must invest in acquiring knowledge about contemporary leadership, with the aim of improving the quality of the care given ${ }^{(25)}$. However, for a change in practice to take place, engagement between leaders and workers is paramount. When leaders do not include their team in the planning of evidence-based practices, the result might turn out to be counterproductive to reach the desired changes ${ }^{(26)}$. 
There is a consensus that nurses are responsible for organizing the work process of their team. In order to lead they must influence, motivate, and stimulate their team so that team members will participate and contribute for the achievement of the established targets ${ }^{(27)}$. In this context, the motivation for using quality indicators is one of the key elements to achieve the intended quality.

Due to the complexity of the factors that influence the management of nursing work, using quality indicators becomes a necessary tool to assess the quality of care ${ }^{(28)}$ and leaders must invest in them. Indicators can point to possible flaws in the quality of the care given and thus enhance the elaboration of a care planning ${ }^{(29)}$.

By using indicators at the ICU, the nurse mobilized workers and trained them for action via information dissemination, dialogue, and technical-scientific updates. Through his guidance and mobilization of the team, the nurse was able to positively influence workers' behavior for the achievement of goals, facilitating the implementation of care by preventing illnesses. It is possible to realize that the target was reached through the exercise of contemporary leadership, which uses dialogue, guidance, and teamwork to change reality, with a resulting improvement in the quality of care.

Leadership is one of the ways for nurses to reach common goals so that efficient communication and teamwork become necessary ${ }^{(17,30)}$. The nursing specialists' team recognizes nurses as examples to be followed to reach the desired goals ${ }^{(27)}$.

Staff size is another issue that directly impacts the quality of care given to patients, directly influencing professionals' health. Management by a nurse that is directed solely toward the needs of the service of his or her unit to meet standards and regulations creates dissatisfaction among the nursing team, increasing stress, dissatisfaction at work, and absenteeism ${ }^{(31-32)}$.

Such dissatisfaction seems to have occurred in one of the stories. Although a criterion was established for deciding on a day off on a holiday, not all of the workers agreed to it. Creating a schedule to define the days off on holidays and special dates can be a good strategy because it does not privilege anybody; however, the ideal situation is that all will take part in this agreement and accept it. Therefore, the turnover due to unforeseen absences and conflicts tends to decrease. To avoid these conflicts, nurses need to resort to dialogue and planning instruments to better distribute the nursing professionals who are part of their staff so that there will be less rotation between sectors $^{(33)}$.

Creating a schedule using criteria may increase workers' morale and motivation, in addition to reducing unforeseen absences, as long as these criteria are discussed with all. This will be a predictor of positive leadership.

Researchers also highlight that an adequate staff size and a well-elaborated schedule work as management instruments for nurses and can organize the work process. Nevertheless, the schedule must be created from criteria established by the team in order to reach a consensus and consequently prevent conflicts in the work environment ${ }^{(34)}$.

Successful leaders who engage with their work and team members are capable of thinking collectively and preventing unnecessary conflicts, once they have the necessary knowledge and abilities to lead their team. Therefore, hospitals need more and more professionals with management and leadership profiles. Managing the team becomes one of the hospital requirements to leader nurses. Together with knowledge and interaction with the organizational environment, this enables greater contributions for the institution's success ${ }^{(17)}$.

Consequently, it is possible to state that successful leaders use essential relational resources and managerial abilities both to promote an adequate bond with their team and to meet the needs of patients and of the institution, creating a healthy environment where balanced relationships are established.

In the management process, nurses' goals are first of all the organization of work and nursing human resources. Leaders place patients' and workers' interests first, enhancing their potentialities and thus motivating them. Consequently, they will produce positive management results and guaranteed quality in care, ultimately benefiting the institution ${ }^{(33)}$.

\section{Study limitations}

It is worth emphasizing, as a study limitation, that the study results reflect the perception by nurses working at a public hospital, a charity hospital, and a for-profit private hospital located in a city in the state of São Paulo, Brazil. This sample does not allow for generalizing the results. Further studies are needed to extend the sample and find out whether the critical requirements established have been enough to characterize nurses' leadership in intensive care units.

\section{Contributions for the nursing field}

This study has the potential to help the advancement of leadership in nursing, as it enables reflecting on the styles and theories adopted by nurses who work at healthcare institutions, especially intensive care units, favoring the adoption of innovative and contemporaries practices that may contribute to the achievement of the desired quality in care in healthcare scenarios both in Brazil and throughout the world.

\section{FINAL CONSIDERATIONS}

In view of the identification of both positive and negative critical incidents and of the analysis of situations described by professionals, it was possible to recognize the easy and difficult situations experienced by nurses that are related to the leadership developed in intensive care units. Some critical situations or incidents interfered with nurses' behavior when leading their nursing team in this scenario. The adopted leadership model was identified as mixed. Researchers highlighted difficulties in the communication process, existing conflicts in the daily professional exercise, and managing people via control-subordination power, which characterizes the adoption of an autocratic leadership style.

However, researchers also highlight that they found some situations where the flexible and participative leadership style was used, characterized by a more intense dialogue and teamwork. In spite of difficult factors experienced and mentioned by nurses, researchers underline that adequate communication that enables the construction of knowledge, the 
engagement of all workers in common goals, and team training were considered facilitating factors in nurses' leadership in intensive care units, which were the setting of this study.

Based on the situations identified, the main results of this study are the urgent need to create an intense communicative process in teams, overcoming the outdated view of hierarchical and informative communication that characterizes traditional management models, and the creation of an educational process to develop leadership as a skill, because one needs knowledge, ability, and attitude in order to lead.

Finally, there is an urgent need to change paradigms in terms of the leadership style adopted in some of the situations identified. The autocratic style that stifles and puts off the team must be replaced by innovative and flexible styles that have room for participation in discussions, contributing creative ideas and co-responsibility for the actions taken.

\section{REFERENCES}

1. Gelbcke FL, Souza LA, Sasso GMD, Nascimento E, Bulb MBC. Liderança em ambientes de cuidados críticos: reflexões e desafios à enfermagem brasileira. Rev Bras Enferm[Internet]. 2009[cited 2016 Mar 09];62(1):136-9. Available from: http://www.scielo.br/ pdf/reben/v62n1/21.pdf

2. Chaves LDP, Laus AM, Camelo SH. Ações gerenciais e assistenciais do enfermeiro em unidade de terapia intensiva. Rev Eletr Enferm[Internet]. 2012[cited 2016 Mar 09];14(3):671-8. Available from: http://www.fen.ufg.br/revista/v14/n3/v14n3a25.htm

3. Conselho Regional de Enfermagem de São Paulo (COREN SP). Parecer Coren-SP 046/2011 - CT GAB nº 046/2011[Internet]. Revisão e Atualização em 2013[cited 2016 Mar 09]. Available from: http://www.portal.coren-sp.gov.br.

4. Yava A, Tosun N, Ünver V, Çiçek H. Patient and Nurse Perceptions of Stressors in the Intensive Care Unit. Stress Health[Internet]. 2010[cited 2016 Mar 09];27:36-47. Available from: https://www.ncbi.nlm.nih.gov/pubmed/27486622

5. Amestoy SC, Backes VMS, Trindade LL, Canever BP. The scientific production regarding leadership in the context of nursing. Rev Esc Enferm USP[Internet]. 2012 [cited 2016 Mar 09];46(1):227-33. Available from: http://www.scielo.br/pdf/reeusp/v46n1/ en_v46n1a30.pdf

6. Gaudencio P. Superdicas para se tornar um verdadeiro líder. 2. ed. São Paulo: Saraiva; 2011. 135 p.

7. Camelo $\mathrm{SHH}$. Professional competences of nurse to work in Intensive Care Units: an integrative review. Rev Latino-Am Enfermagem[Internet]. 2012[cited 2016 Mar 09];20(1):192-200. Available from: http://www.scielo.br/pdf/rlae/v20n1/25.pdf

8. Gonçalves HS, Mota CMM. Liderança situacional em gestão de projetos: uma revisão da literatura. Produção. 2011;21(3): 404-16.

9. Bernardes A, Cecilio LCO, Gabriel CS, Carvalho MB. Collective and decentralized management model in public hospitals: perspective of the nursing team. Rev Latino-Am Enfermagem[Internet]. 2011[cited 2016 Mar 09];19(4):1003-10. Available from: http://www. scielo.br/pdf/rlae/v19n4/20.pdf

10. Balsanelli AP, Cunha ICKO. Ideal and real leadership of nurses in intensive care units at private and publichospitals. Cogitare Enferm[Internet]. 2016[cited 2016 Mar 09];21(1):01-07. Available from: http://www.scielo.br/pdf/rlae/v23n1/0104-1169-rlae-23-01-00106.pdf

11. Chair AR. Frontline leadership, innovation and best practice: 10 hot topics every critical care nurse should be aware of. Nurs Crit Care[Internet]. 2015[cited 2016 Mar 09];20(1):3-4. Available from: http://onlinelibrary.wiley.com/doi/10.1111/nicc.12153/epdf

12. Flanagan JC. A técnica do incidente crítico. Arq Bras Psic Aplic. 1973;25(2):99-141.

13. Dela Coleta JÁ, Dela Coleta MF. A técnica dos incidentes críticos: 30 anos de utilização no Brasil, na Psicologia, Administração, Saúde e Educação. Taubaté: Cabral Editora e Livraria Universitária; 2004. 130 p.

14. Hospital das Clínicas da Faculdade de Medicina de Ribeirão Preto (HCFMRP). Esclarecimento, História do HCFMRP e Unidade de Emergência[Internet]. 2015[cited 2016 Mar 09]. Available from: http://www.hcrp.fmrp.usp.br

15. Cadastro Nacional de Estabelecimentos de saúde (CNES). Consulta Estabelecimentos: Módulo Hospitalar - Leitos[Internet]. 2015[cited 2016 Mar 09]. Available from: http://cnes.datasus.gov.br

16. Minayo MCS. O desafio do conhecimento: pesquisa qualitativa em saúde. 12. ed. São Paulo: Hucitec, 2010.

17. Chianca TCM. Análise sincrônica e diacrônica de falhas na assistência de enfermagem em pós-operatório imediato. Rev Bras Enferm[Internet]. 1998[cited 2016 Mar 05];51(2):346-7. Available from: http://www.scielo.br/pdf/reben/v51n2/v51n2a16.pdf

18. Paula GF, Figueiredo ML, Camargo FC, Iwamoto HH, Caixeta CRCB. Concepções de liderança entre enfermeiros assistenciais de um hospital do norte de Minas Gerais. Rev Eletrôn Enferm[Internet]. 2012[cited 2016 Mar 09];14(4):821-30. Available from: http://www.fen.ufg.br/revista

19. Santos JLG, Lima MADS, Pestana, AL, Garlet, ER, Erdmann, AL. Challenges for the management of emergency care from the perspective of nurses. Acta Paul Enferm[Internet]. 2013[cited 2016 Mar 09];26(2):136-43. Available from: http://www.scielo.br/pdf/ ape/v26n2/en_v26n2a06.pdf

20. Gomes AR, Cruz J. Abordagem carismática e transformacional: modelos conceptuais e contributos para o exercício da liderança. Psicol. USP. 2007;18(3):143-61. 
21. Strapasson MR, Medeiros CRG. Liderança transformacional na enfermagem. Rev Bras Enferm[Internet]. 2009 [cited 2016 Mar 09];62(2):228-33. Available from: http://www.scielo.br/pdf/reben/v62n2/a09v62n2.pdf

22. Wong CA, Laschinger HKS. Authentic leadership, performance, and job satisfaction: the mediating role of empowerment. J Adv Nurs[Internet]. 2012[cited 2016 Mar 09];69(4):947-59. Available from: https://www.ncbi.nlm.nih.gov/pubmed/22764828

23. Santos I, Erdmann AL, Santos JLG, Klock P, Martins VV, Brandão ES. The education of healthcare management: a view from the graduates - Grounded Theory. Online Braz J Nurs[Internet]. 2012[cited 2016 Mar 09];11(3):621-37. Available from: http://www. objnursing.uff.br/index.php/nursing/article/view/3924

24. Silva VLS, Camelo SHH. A competência da liderança em enfermagem: conceitos, atributos essenciais e o papel do enfermeiro líder. Rev Enferm UERJ[Internet]. 2013[cited 2016 Mar 09];21(4):533-9. Available from: http://www.objnursing.uff.br/index.php/ nursing/article/view/3924

25. Balsanelli AP, Cunha ICK. O. Nursing leadership in intensive care units and its relationship to the work environment. Rev LatinoAm Enfermagem[Internet]. 2015[cited 2016 Mar 09];23(1):106-13. Available from: http://www.scielo.br/pdf/rlae/v23n1/0104-1169rlae-23-01-00106.pdf

26. Oye C, Mekki TE, Jacobsen FF, Forland O. Facilitating change from a distance: a story of success? A discussion on leaders' styles in facilitating change in four nursing homes in Norway. J Nurs Manag[Internet]. 2016[cited 2016 Mar 09];24:745-54. Available from: http:// onlinelibrary.wiley.com/doi/10.1111/jonm.12378/abstract

27. Souza RB, Ilha S, Lima CLF, Gracioli MAS, Backers DS, Nicola GDO. Organização e liderança no trabalho do enfermeiro: percepção de enfermeiros e técnicos de enfermagem. Rev Enferm Cent O Min[Internet]. 2013[cited 2016 Mar 09];3(2):687-95. Available from: http://www.seer.ufsj.edu.br/index.php/recom/article/view/360

28. Vieira APM, Kurcgant, P. Quality indicators of the management of human resources in nursing: point of view of registered nurses. Acta Paul Enferm[Internet]. 2010[cited 2016 Mar 09];23(1):11-5. Available from: http://www.scielo.br/pdf/ape/v23n1/02.pdf

29. Nogueira LS, Sousa, RMC, Padilha, KG, Koike, KM. Características clínicas e gravidade de pacientes internados em UTIS públicas e privadas. Texto Contexto Enferm[Internet]. 2012[cited 2016 Mar 09];21(1):59-67. Available from: http://www.scielo.br/pdf/tce/ v21n1/a07v21n1

30. Oliveira AV, Souza TFSC, Silva FJ, Figueiredo NM. A. Percepção dos técnicos e auxiliares de enfermagem em relação à supervisão na Unidade de Terapia Intensiva. Rev Pesqui Cuid Fundam. [Internet]. 2010[cited 2016 Mar 09];2(3):1214-23. Available from: http://dialnet.unirioja.es/servlet/articulo?codigo $=3652206$

31. Blanco BM, Valente GSC, Lima CA, Oliveira ACL, Correa MB. A importância da liderança do enfermeiro no gerenciamento das relações interpessoais entre a equipe de saúde. Rev Pesqui Cuid Fundam[Internet]. 2013[cited 2016 Mar 09];5(3):211-17. Available from: http://www.seer.unirio.br/index.php/cuidado

32. Rogensk KE, Fugulin FMT, Gaidzinskir R, Rogenski NMB. Nursing care time in a teaching hospital. Rev Esc Enferm USP[Internet]. 2011[cited 2016 Mar 09];45(1):223-9. Available from: www.scielo.br/pdf/reeusp/v45n1/en_31.pdf

33. Spagnol CA, Santiago GR, Campos BMDO, Badaró MTM, Vieira JS, Silveira APDO. Conflict situations experienced at hospital: the view of nursing technicians and auxiliaries. Rev Esc Enferm USP[Internet]. 2010[cited 2016 Mar 09];44(3):803-11. Available from: http://www.scielo.br/pdf/reeusp/v44n3/en_36.pdf

34. Silva AC, Rosa MA, Lourenção DCA, Jensen R. Planejar, liderar e comunicar: desafios para o gerenciamento de enfermagem. Rev Nurs. $2012 ; 277-82$. 